\title{
The Early Organizational Management Theories: The Human Relations Movement \& Business Ethical Practices Pioneered By Visionary Leader Mary Parker Follett \\ Joseph W. Kennedy, (E-mail: jwk21@cox.net), Edward Waters College Joseph Heinzman, International College \\ Bahaudin G. Mujtaba, (E-mail: mujtaba@nova.edu), Nova Southeastern University
}

\begin{abstract}
In today's business environment, managers make crucial decisions that affect the longevity of their organizations. We propose that Mary Parker Follett's theories enhance the perspective of ethical standards and promote an organization's overall value. The $21^{\text {st }}$ century will require organizations to create overall value for all stakeholders; these constituent groups include employees, partnerships, national consumers, international consumers, domestic markets and global markets. The ethics in creating value for the organization is based on the internal and external perception of value by all stakeholders. The goal of this essay is to provide an understanding of the role of ethics in an organization.
\end{abstract}

\section{INTRODUCTION}

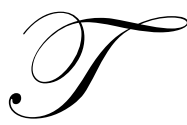

his essay identifies the contribution of Mary Parker Follett, a management theorist in the early $20^{\text {th }}$ century of the United States. The Management discipline was divided into three main schools of thought during the early $20^{\text {th }}$ century. The Management Schools of Thought during that time were: The Classical School of Management, The Human Relations School of Management, and the Human Resource School of Management. This paper will compare and contrast Mary Parker Follett's various philosophies and theories of ethical management from the past to current applicability, as well as her overall contributions to Management history.

Daniel A. Wren (1994), the author of his published work on, "The Evolution of Management Thought" provides insights of early management theorists. The book reports the theorist beliefs, identifies their works and establishes their philosophy during the time frame of their era. However, many of Wren's encapsulations of the theorists reflect a current or modern point of view, which reveals that these theorists were ahead of their time, such as Mary Parker Follett. Before introducing the theories of Mary Parker Follett, it is very important to reflect on the nature of work conditions of the late 1900's. Prior to the industrial revolution, most Americans were engaged in farming or small businesses, such as shopkeepers or shoemakers. There was no history of working in large groups (with the exception, perhaps, of the military) and people generally lived and worked in the same small geographic area, most of their lives. With the advent of the industrial revolution, however, towns began to grow around factories and people began to work under one roof with numerous other people. Supervisors were required and management was needed to handle the different intricacies of job specialization. The tradition of growing food for one's family or working where an end product was easily identified and "owned" was decreasing. Much has been written about the resulting alienation from work that people felt with the early factory system; the nature of work did indeed drastically change. What were the early factories like? No air-conditioning, uncarpeted floors, or uncomfortable surroundings. Yet, employees at that time worked without much complaint perhaps due to the dominant Protestant Work Ethic of the time. The Protestant Work Ethic taught that work was inherently moral and their reward for hard work would come to them in Heaven. Today, there are at least two other work ethical standards. The Worth Ethic, provided employees, 
especially professional employees, meaningful work. They were willing to work hard but conditions must be motivating and the work satisfying. The new work philosophy today, the Leisure work Ethic, suggests that employees only work to earn the money to pursue their real interests, travel, hobbies, and family time.

\section{LITERATURE REVIEW}

The Classical school of Management period began around 1881 with Frederick W. Taylor's first motion study and was the prevailing thought until the rise of the social era in 1924 with the first Hawthorne study. The theorists of the classical school believed in the concept of the "Economic Man," (Wren, 1994, p. 43) employees were motivated by money. Payment at that time was made on the "piece rate," i.e., employees got paid per unit produced. There were two important streams of thought during the Classical period: Scientific Management lead by Frederick W. Taylor and the Human Relations movement by Mary Parker Follett and Chester Barnard. (Wren, 1994 p. 223) Scientific management was driven by efficiency, to find the one best way to perform the job. Thus, to decrease wasted processes or motions that hinders the company's time. The managers' main responsibility was to train their workers, in this one best way, efficiency would be improved and overall productivity would increase. One of Frederick W. Taylor's most important aspects of Scientific Management was the development of combining science into business operations or "Systematic Management," and to have other great minds acknowledge and collaborate on his philosophy. (Wren, 1994 p.229) The Human Relations movement came about during the latter part of the Scientific Management period, and termed the Neo-Classical School due to the differences in the Classical School of Management.

The Human Relations movement or what we call today, "Organizational Behavior" is the study of people within organizations, and how they relate to their internal and external environments. Thus, Follett, the Behavioral and Holistic schools of management contrived the founding of two schools of management thought. Follett was one of the first researchers to examine the relationships of holistic and behavioral activities, thus her main attraction was the study of groups, which was based on the interdependent parts of an organization contributing to the sum of its parts, "employee integration" for the entire organization. (Parker, 1984, p. 738)

Mary Parker Follett was one of the few women who were making a difference, predominantly during a male dominated business period, during her time $(1868-1933)$. Follett is generally more studied by public administration majors than business administration majors because of her early work with social service agencies, however her interest within the business area was predicated on the fact that she was interested and sought relevance of integrative unity. (Wren 1994, p. 259) She was a popular speaker of the day and made presentations to many businessmen's groups on her views of how individual behavior influenced work. This was a very unorthodox viewpoint at that time, but heralded the next school of thought. Follett's writing of the interrelationships of the Behavioral and Holistic school's was to capture the essence of integration within business, to replace inadequate or damaging hierarchical controls which de-humanize employee value, and allow corruption within organizations to emerge. (Parker, 1984, p. 737) These realities are of concern today, with the advent of unethical practices by organizational leaders, such as Firestone, Enron and WorldCom.

Mary Parker Follett identified three compelling steps of giving orders, which internalizes ethical decision making on the part of the business leader, edited by Fox and Urwick (1973, p. 21) Follett stated that experiential learning, "the conscious" affect toward our behavior, turned inward, to learn from what we do as business leaders. The three steps to giving orders:

\section{Step One:}

Conscious Attitude: The realization that people can imply context and act appropriately. 


\section{Step Two:}

Responsible Attitude: Ethical behavioral constraints, which determine the moral judgments of different people's perceptions. This is based on the manner in which the person giving the order will act on, based on individual preferences.

\section{Step Three:}

Experimental Attitude: Follett identified this third aspect as the test phase, to experiment and review findings to determine the best set of circumstances in issuing orders.

According to Follett's writing (Fox and Urwick, 1973, p. 21) giving the correct orders should be ascertained by the greatest opportunity, which culminates the best set of factors for the organizational members. This is a very important aspect of ethical behavior for business leaders. Organizational leaders should not base their orders and decisions on what they perceive are right for them. Rather, they should base their decisions, orders and actions based on the creation of overall value of the entire organization. According to Follett, the universal goal of organizations was "Integration" of individual effort into a synergistic whole, the group or team philosophy, which culminates the entire behavioral aspects of all organizational members for the integration effort. According to Follett, the business leaders' work is to provide a basis of understanding for all organizational members, by allowing them to make cognitive choices, thus all information is shared openly, seeking to solve organizational problems, for the betterment of the entire organization. (Wren \& Greenwood, 1998, p. 195) Follett also stated that true powers in organizations are based on the commingling of various organizational teams through "effective relations." The leader of the organization divulges his/her will to create a synergy within the organization, through organizational integration. (Fox and Urwick, 1973, p. 213)

Mary Parker Follett's "Universal Principle" edited by Graham (1995, p. 37) was a "circular or reciprocal response" which stated that no communication transactions should be seen as one way communication from supervisor to employer, but that every message had a result which served as feedback to the sender. Follett stated that Edwin B. Holt mathematician 1873-1946; "The concept of consciousness" book (Fox and Urwick, 1973) propagates her understanding and belief of behavioral processes for the circular response. Holt identified that social factors and business factors influence the behavior of trade unions:

The Object (environment) is influenced by the Subject (situation, event or process) and the Subject (situation, event or process) is influenced by the Object (environment). Thus, a circular reciprocal response is created. (Graham, 1995, p. 37)

Follett identified that in order to discern this process, the Object (environment) is either an independent variable or an interdependent variable, and each scenario precipitates different factors based on each observed or implied response. This process is instantaneous, however, if a leader of an organization fails to consider the ramifications of their communications or orders, people in business may respond to it in the wrong way, which can result in unethical practices by an organization. Another factor discussed by Follett, is the level of job satisfaction an employee may have towards its employer (Graham, 1995, p. 45). Employees respond to intrinsic and extrinsic factors, such as:

- Wages, profit share, employee benefits.

- $\quad$ Leadership and management proficiency from the organization.

- Working conditions.

- Immediate employee needs and desires.

- $\quad$ Future employee aspirations.

According to Follett, employees respond to different sets of intrinsic and extrinsic factors differently, based on the employees own desires, internally or externally. However the employee discerns value based on external factors, such as what other employees receive, increased pay, increased benefits, advanced training and development, 
increased opportunities by others. Thus, employee needs are espoused based on changing external factors by the organizational environment. In another article by Bandura \& Schunk (1989) they state the same philosophy that employees determine their own self-efficacy based on comparisons with others. Follett stated, that intrinsic and extrinsic behavioral processes are linked, and must be analyzed together to determine the best set of stimuli for organizational behaviors. (Graham, 1995, p. 44-45)

One of the key elements of Mary Parker Follett's contribution to the Management discipline is her belief that Organizational Leadership is "Situational," leadership is throughout an organization, at different levels and in different situations. When leadership transforms an organization to higher levels, achieving greater market share, or when an organization becomes the dominant business within their market, leadership according to Follett has achieved the genius level. (Follett, 1933, p. 51) Follett's Law of the Situation was very prophetic in that she taught that there is no one best way to do anything, it depends on the situation. The business leader must appropriately diagnose the situation, and visualize the situation entirely, in order to correlate its indigenous parts. The business leaders' most notable asset is his/her ability to recognize changing situations and to respond affectively. (Follett, 1933, p. 51) This was in direct contrast to the Scientific Management approach of her time. In today's business environment, Mary Parker Follett's philosophy is correct; the situation depends on the correct course of action to be taken by the organizational leader; however, unethical practices by an organization can be caused by the deficiency of affective leadership. Inter-organizational integration is a philosophy of thought concerning the interaction of organizations, either internally or externally integrating to compete within their market and was termed "Inter-organizational relationships (IOR)" by Oliver (1990). Oliver espoused that IOR's are necessary in businesses today, because organizations must enhance its decision-making frameworks in order to adapt to customers, partnerships and competitors demands. The six factors of IOR's identified by Oliver enhance the organizations ability to integrate based on generalizable or relationship-specific identifiers to meet the organizations specific needs. Interorganizational relationships include employees, partnerships, national consumers, international consumers, domestic markets and global markets.

Leader-Member Exchange (LMX) refers to leader-employee dyadic relationships. It is further postulated that these relationships affect employees' work attitudes and well-being. (Epitropaki, and Martin, 1999). Leadership has many forms such as transformational, transactional (Scandura and Schriesheim, 1994), and situational (Hersey and Blanchard, 1982).

Transactional leadership is a form of leadership that recognizes the needs of their employees and exchanged rewards for appropriate levels of effort and performance. Therefore, the transactional leader motivates members to perform as expected (Den Hartog, Muijen and Koopman, 1997). Transformational leadership moves beyond transactional leadership to increase the awareness for valued outcomes by expanding and elevating employees' needs and by encouraging employees to rise above self-interest. Therefore, transformational leaders inspire the members to rise above original expectations (Hartog, Muijen and Koopman, 1997). Contingent rewards are the reinforcements that a leader provides in exchange for employee appropriate levels of effort and performance. Contingent rewards and LMX are related to job satisfaction (Bycio, Hackett and Allen, 1985).

Transformational leadership affects the results of LMX on affective organizational commitment, intention to leave an organization, and job satisfaction. (Bycio, Hackett, and Allen, 1985). Other research has consistently shown that LMX was positively correlated to organizational commitment, job satisfaction and well-being (Epitropaki and Martin, 1999).

"Attitudinal or Affective Organizational Commitment refers to the employee's emotional attachment to, identification with, and involvement in the organization and its goals. Affective commitment results in the employee wanting to remain in the relationship" (Clugsten, C., Howell, J.P., and Dorfman, P.W. (2000).

The transformational leadership scales have strong positive relationships with affective organizational commitment, which was significantly larger than the scales relationship to continuance, or normative commitment (Bycio, Hackett, and Allen, 1995). This data ties LMX to affective commitment and to a much lesser amount to continuance and normative commitment. 
There are five job characteristics, autonomy, skill variety, task identity, feedback, and task significance that influence the individual's ability to look at the range of flexibility at work. These characteristics are objective job dimensions and are measured by the Job Diagnostic Survey (JDS). Job characteristics, autonomy, skill variety, task identity, task feedback, and task significance are related to job satisfaction and organizational commitment (Hackman and Oldman, 1975).

Autonomy can be viewed as the extent to which employees have a say in scheduling their work, and the freedom to do what they want on a job (Bhuian and Menguc, 2002). Organizations try to enrich jobs by providing autonomy and employees reciprocate by identifying themselves more closely with the organization (Tyagi and Wotruba, 1993.) Autonomy can influence the level of the employee's organizational commitment (Hunt, Chonko, and Wood, 1985).

Skill variety refers to the range of options that an employee has available in accomplishing work (Shaffer and Harrison, 1998). Skills are the abilities that an employee has available to perform a task. Skill variety is the degree that a job requires a variety of different activities to carry out the work, which involves the use of a number of different skills and talents of the employee (Hackman and Oldham, 1975). Skill variety is linked to organizational commitment (hunt, Chonko, and Wood, 1985).

Task identity is the degree that a job requires the completion of a task, identifiable piece of work, from the beginning to the end of the effort and having a visible outcome (Hackman and Oldham, 1975). Task Identity is linked to organizational commitment (Hunt, Chonko, and Wood, 1985).

Task feedback is the information that an employee receives back that lets them know how they are performing at the job (Shaffer and Harrison, 1998). This feedback can be from agents or other people. Agent feedback is performance feedback received from supervisors or co-workers while feedback from others is performance feedback from dealings with other organization members or external sources such as clients or customers (Hackman and Oldham, 1975). Feedback is a form of communications within an organization and is important in that it has effects on job performance and job satisfaction. Effective communications has been shown to be related to increased organizational commitment (Andrews and Kacmar, 2001). Feedback most likely comes from five sources; supervisors, co-workers, clients/customers, salary/performance assessment, and the internal feeling an individual has about their own performance (Andrews and Kacmar, 2001).

Task significance is comprised of the activities that an employee is to perform and the way that the employee should perform them (Churchill, Ford, and Walker, 1976).In addition, task significance is the degree that a job has significant impact on the lives or work of other people whether in the organization or in the external environment (Hackman and Oldham, 1975).

These five sources are components of job satisfaction, with the fifth source being termed as "met expectations." The other elements support the association of job satisfaction to the feedback antecedent of affective organizational commitment and to the feedback element of job characteristics. The relationships of supervisor feedback are considered the most important (Geller and Herold, 1975). The most informative order of importance for job performance feedback found in one study was the employee's met expectations, the task, supervisors, co-workers and the organization (Herold et al., 1987).

Job satisfaction is the affective reactions employees have toward their work situation (Dubinsky et al, 1992). Job satisfaction is composed of several elements, customers, overall job, co-workers, supervision, company policy and support, pay, promotion and advancement, age, tenure and met expectations (Churchill, Ford, and Walker, 1974), (Naumann, Widmier and Jackson, 2000), (Shaffer and Harrison, 1998). Customers are measured based on attributes related to customers being fair, respectful of employee judgment, reasonable, friendly, loyal, understanding, accessible, organized, trustworthy, and interested in the employee.

The overall job is evaluated based on work attributes such as the work being creative, valuable, exciting, satisfying, worthwhile, productive, interesting, and challenging. It measures how much freedom of judgment and 
sense of accomplishment is associated with the overall job. Individuals with a high level of job involvement have higher performance than those who are not highly involved and who perceive effective organizational communications have a higher level of job satisfaction (Orpen, 1997). Co-workers are measured based attributes such as the co-workers being, stimulating, sociable, pleasant, friendly, loyal, intelligent and responsible. It measures how much fellow workers help each other when work falls behind and looks at how well workers get along with each other. Supervisors are measured based on attributes such as the supervisor being, up-to-date, well organized, fair, intelligent, and tactful, a problem solver, and a team builder. It measures how well the supervisor, develops employees' potential, stimulates sales efforts, puts needs of employees before personal success, gives praise for work well done, lives up to promises, gets employees' ideas, and gets problems across to management. Trust is a factor in determining the relationship between a supervisor and an employee. Trust, the extent upon which a relationship partner can be relied, has been viewed as the perceived credibility and benevolence of a target of trust that is comprised of objective credibility and benevolence, the extent to which one partner is concerned with the well being of the other, (Doney and Cannon, 1997). Employees who trust their leaders have a higher level of job satisfaction and are more committed to an organization (Flaherty and Pappas, 2000). The job satisfaction and organizational commitment are related to the employee's perception of the supervisor employee or LMX relationship, and that trust is an important element. Company policy and support is measured based on attributes such as employee benefits, management planning, employee training, sales promotions, communications, employee concern consideration, sales goal establishment, job knowledge, product quality, management strength, fair and honest, employee welfare consideration, profit sharing, home office support, intra departmental cooperation, and clearness of management instruction. Pay is measured based on attributes related to similar work in other companies, as an incentive to increase sales, as a result of selling ability, as an ability to get luxuries, related to other employees within company, as an ability to pay normal expenses, and relative amount of pay measured as high. Promotion and advancement is measured based on attributes related to being opportunity limited, based on ability, ample, regular, fair, and reasonable. The instrument also looks at job progression potential.

In Harrison and Hubbard's study, age was found to be predictive of organizational commitment (Harrison and Hubbard, 1988). Leader-member organizational tenure difference moderates the relationship between LMX, organizational commitment, and job satisfaction. Employees with a large difference in organizational tenure from their leader and a low LMX reported lower organizational commitment and job satisfaction than members with a relatively small difference (Epitropaki and Martin, 1999). Contextual factors can have a strong impact on the tenure, job satisfaction, organizational and LMX relationship (Green et al., 1996).

Met Expectations have been found to be related to job satisfaction and organization commitment (Naumann, Widmier, and Jackson, 2000). One definition of the met expectations theory suggests that met expectations is the discrepancy between what individuals encounter on the job and what they expected to encounter on the job. This discrepancy of met expectations affects the individual's propensity to leave, organizational commitment and job satisfaction. Met expectations is difficult to measure since employees would have to be surveyed prior to employment on their expectations and surveyed again post employment to measure the delta (Irving and Meyer, 1994).

\section{DISCUSSION}

This paper explores the possible effects of ethics in the behavioral realms of leader-member exchange, job characteristics/motivation, and job satisfaction. Ethics can be defined as moral obligations involving the distinction between right and wrong. Business, management, or organizational ethics defines a framework within a going concern (Kreitner, 2004).

Follett's most cited works have dealt with organizational theory (Fry \& Thomas, (1996). Literature suggests that organizations need to pay more attention to their employee's emotional and spiritual needs (Eylon, 1998). Leadermember exchange, job characteristics and job satisfaction are important organizational behaviors that fit within the over-arching organizational theory that address employees' emotional and inferred spiritual needs. This paper addresses spiritual needs as ethical needs for the purpose of organizational theory focus. 
LMX addresses the dyadic relationship between a leader and a follower. Follett thought that the responsibility of the firm was to develop the individuals and groups potential, that all interactions had to consider the situational context and that there are nonlinear dynamics at work in the behavioral setting. The individual's development depends on a positive relationship with the immediate leader. The nature of a positive or negative LMX effects the job satisfaction of the employee, the employee's organizational commitment, and the employee's propensity to cognitively withdraw or to leave the organization.

Members form networks of relationships with coworkers just as leaders form relationships with other members and leaders. The interaction of these forces is nonlinear (Mendenhall, et al, 2000) and circular (Boje \& Rosile, 2001) where the relationships between these variables are actually interrelationships. A member who is dissatisfied with their leader's interaction may approach a co-worker who has a good relationship with the leader to intervene. The co-worker may approach a fellow co-worker who has a different leader to request intervention of that leader to the first mentioned leader. While this may appear linear there are consequences I all of the interactions that could change the nature of the relationships of the first leader, first member, second member, second leader geometrically and bilaterally. This interactive multi-directional chain of events is in effect nonlinear and tends to create chaotic stimuli in the organization.

Follett contended that situational factors further impacted this nonlinear leader-member process within what she saw as a social setting not a business setting (Eylon, 1998). This pertabates and complicates the nonlinear LMX networking scenario causing a lack of organizational focus. Follett contended that collaboration brings focus through an iterative and ongoing exchange process between the leader and the member.

Individuals fit within several layers of organizational culture that further affects the complexity and boundaries of nonlinearity. These levels are individual level, organizational culture, industry culture, national culture, supra-culture or socio-economic-theological and a universal level (Srnka, 2004). The effect of the levels helps define relationships and bound limits of exchange and nonlinearity.

All of these influences culminate in layers of ethical perceptions and influences. The ethical perspectives of leaders, members, co-workers, leadership superiors, organizations and geographical cultures all impact behaviors at multiple levels. The establishment of ethical guidelines for leaders and members provide a fixed point for acceptable behaviors (Caza et al, 2004), which pertains to broad organizational and LMX environments. Ethical problems are leadership issues. The hiring of leader and members who have relatively high ethical standards is important to the functioning of the firm Prospective employees will have lower comfort levels in working with peers and managers who exhibit lower ethics levels (Keith et al, 2003).

Job characteristics' scoring produces a motivational potential output that provides a common measure for industry. The calculation is (Task Significance + Task Identity + Skill Variety) $/ 3+$ Autonomy + Feedback and the generally accepted standard or average score is 120 (Hackman and Oldham, 1975). Autonomy deals with the relationship of the member and the leader; therefore, ethical behaviors are perceived in the metering out of degrees of autonomy between members in the same job. The employees inferred perception of fairness in the degree of autonomy for peers performing the same task as the member results in an impact on the members' motivational potential. The nature, quantity and quality of feedback from the leader to the member will result in an impact on the member's level of motivational potential. Positive, frequent, copious feedback tends to encourage favorable employee satisfaction and increased motivational potential. An inequality of feedback between member peers would be perceived as unfair and result in lowered motivational potential. Fairness or justice is a value in the framework of workplace spirituality or ethics (Jurkiewicz and Giacolone, 2004). Therefore the level of perceived fairness in task autonomy and task feedback is important in determining the overall motivation of the member.

Job satisfaction relies on the ethical treatment of the member by the leader since the relationship of the leader to the member is the most significant determinant of overall job satisfaction. The importance of a member having a high level of job satisfaction is amplified if the member is interfacing with customers. There is a relationship between organizational job satisfaction and customer satisfaction when employees are interfacing directly with the customer. 
Ethics impact an organization in a multitude of ways including leader-member exchange, motivational potential and job satisfaction. In turn, these organizational behaviors impact the ability to hire and retain critical skills necessary for the perpetuation of the firm.

The Importance to Institutions of Higher Learning due to the increased exposure of unethical activities by companies such as Enron, Tyco, WorldCom and others has greatly expanded the importance of the collegiate ethics curriculum. Corporate lack of social responsibility coupled with pressure from professional associations and collegiate accrediting agencies has encouraged the expansion of the student ethics studies (Baetz \& Sharp, 2004). Undergraduate courses contain ethical parts or discussions but do not focus on the issue of ethics adequately. An ethics curriculum should be considered at the undergraduate level and the graduate curriculum investigated.

The works of Mary Parker Follett could be integrated into undergraduate studies to compliment corporate social responsibility, business ethics, and employee ethics curricula. Her works are so extensive and underlie a wide range of current business processes that individual courses based on her works could be offered. A Business ethics concentration could be offered within the business administration curriculum utilizing much of her work

\section{CONCLUSION \& IMPLICATIONS FOR FUTURE RESEARCH}

Code of Ethics and business ethical operations are a significant field of study and a focused set of researchers are needed to study the significant factors that determine normative business ethical behavior (Cooper, 2004). Businesses react to legal and stakeholder influences and develop a corporate social responsibility. The ethical implications of a business are commensurate with the decision makers within the organization. Organizations develop very different guidelines since these constraints or influences can come from local, state, national, and international governments due to the diversity of stakeholders. Implied ethical decisions are important for businesses to increase their overall value of their firm. Research could develop core or guiding codes of ethics on a national and global basis that organizations could expand and evolve into a corporate ethical umbrella. In today's global business markets it is imperative for companies to understand their stakeholders, (internal and external) in order for the firm to maximize its long term value. A longitudinal study of the relationship of ethics to, leader member exchange, motivational potential, and organizational commitment and job satisfaction would greatly enhance the understanding of the effects of changing levels of ethics on overall organizational behavior and the ability to acquire and retain employees. The linear plus nonlinear effects of the ethical relationship to LMX could be detected by longitudinal testing of the relationship between LMX and ethics using established research instruments.

Mary Parker Follett provided a plethora of philosophical and pragmatic information in her works that encompassed business ethics, collaboration of leaders and members through integration, situational leadership, circular and nonlinear logic. Follett's ethical research has greatly contributed to modern business practices. Empirical studies of the relationship of ethics within an organizational behavior context and the expansion of undergraduate business ethics curricula will be a testament to her works and bring well deserved posthumous recognition. Follett's contribution to ethical leadership was based on implied factors which leaders must apply within their long term plans which will manifest into increasing overall value in terms of profitability and reputation with all their internal and external stakeholders.

\section{REFERENCES}

1. Baetz, M.C. and Sharp, D.J. (2004). Integrating ethics content into core business curriculum: Do core teaching materials do the job? Journal of Business Ethics, 51(1), 53-62.

2. Bandura, A. and Schunk, D. (1989). Cultivating Competence, Self-Efficacy, and Intrinsic.

3. Interest Through Proximal Self-Motivation. Journal of Personality and Social Psychology 41, 586-598.

4. Boje, D.M. and Rosile, G.A. (2001). Where's the power of empowerment? Answers from Follett and Clegg. The Journal of Applied Behavioral Science, 37(1), 90-117.

5. Caza, A., Barker, B.A., and Cameron, K.S. (2004). Ethics and ethos: The buffering and amplifying effects of ethical behavior and virtuousness. Journal of Business Ethics, 52(2), 169-178. 
6. Cooper, T.L. (2004, Jul/Aug). Big questions in administrative ethics: a need for focused, collaborative effort. Public Administration Review, 64(4), 395-407.

7. Eylon, D., (1998). Understanding empowerment and resolving its paradox: Lessons from Mary Parker Follett. Journal of Management History, 4(1), 16-31.

8. $\quad$ Follett, M. P., (1918). The new state: group organization the solution of popular government. London. Longmans, Green \& Co.

9. Follett, M.P. (1933), The essentials of leadership, lecture delivered at Department of Business Administration, London School of Economics and Political Science. January, reprinted from the book, Freedom and Coordination, Chapter IV, pp. 47-60. edited by L. Urwick (1949), The Management Publications Trust, Ltd.

10. Follett, M.P. Dictionary of American Biography, Supplements 1-2: To 1940. American Council of Learned Societies, 1944-1958. Reproduced in Biography Resource Center. Farmington Hills, Mich.: The Gale Group. 2004. http://0-galenet.galegroup.com.novacat.nova.edu:80/servlet/BioRC.

11. Fox, E.M. and Urwick, L. (Eds.). (1973). Dynamic administration: The collective papers of Mary Parker Follett. $2^{\text {nd }}$ ed. Camelot Press Ltd, London.

12. Fry, B.R. and Thomas, L.L. (1996). Mary Parker Follett: Assessing the contribution and impact of her writings. Journal of Management History, 2(2), 11-17.

13. Gable, W. and Ellig, J. (1993). Introduction to Market Based Management. Center for Market Process, Fairfax, VA:

14. Gibson, J. (1985). Reading and Exercises in Organizational Behavior. Academic Press, New York.

15. Gibson, J. (1995). The Supervisory Challenge. $\left(2^{\text {nd }}\right.$. Ed.). Prentice-Hall, Englewood Cliffs, N.J.

16. Graham. P. (Eds.). (1995). Prophet of management. Harvard Business School Press, Boston, MA.

17. Hackman, J.R. and Oldham, G.R., (1975). Development of the job diagnostic survey. Journal of Applied Psychology, 60(2), 159-170.

18. Holt, E., (1973). The concept of consciousness. Arno Press, New York.

19. Jones, G, R. and George, J., M. (2003). Contemporary Management. ( $3^{\text {rd }}$ Ed). McGraw-Hill, New York.

20. Jurkiewicz, C.L. and Giacalone, R.A., (2004). A values framework for measuring the impact of workplace spirituality on organizational performance. Journal of Business Ethics, 49(2), 129-142.

21. Keith, N.K., Pettijohn, C.E., and Burnett, M.S., (2003). An empirical evaluation of the effect of peer and managerial ethical behaviors and the ethical predispositions of prospective advertising employees. Journal of Business Ethics, 48(3), 251-265.

22. Kreitner, R. (2004). Management. ( $9^{\text {th }}$ Ed.). New York, Houghton Mifflin.

23. Mendenhall, M.E., Macomber, J.H., and Cutright, M., (2000). Mary Parker Follett: Prophet of chaos and complexity. Journal of Management History, 6(4), 191-202.

24. Mujtaba, B. (2003). Ingredients for Empowering the Afghan Workforce to Deliver Superior Value. Published by the Society for Afghan Engineers (SAE). Proceedings titled, International Planning Conference for the Empowerment of Afghan Professionals. Hoboken, New Jersey. October 3-6, 2003.

25. Mujtaba, B. and Najafi, F. (2004). Building Trust and Productivity through Effective Communication and Leadership in the Workforce. International Society for Productivity and Quality Research (ISPQR)

Proceedings on "Economic Renewal through Productivity." Conference in Miami, Florida. - February 15-19, 2004. (http://www.ispqr.com).

26. Oliver, C. (1990). Determinants of Interorganizational Relationships: Integration and Future Directions. The Academy of Management Review, 15 (2), 241.

27. Parker, L.D. (1984). Control an organizational life: The contribution of Mary Parker Follett. Academy of Management Review, 9(4), 736-745.

28. Pohlman, R. A. and Gardiner, G.S. (2000). Value-Driven Management: How to Create and Maximize Value Over Time for Organizational Success. ISBN: 0-8144-0485-5.

29. Srnka, K.J. (2004). Culture's role in marketers' ethical decision making: An integrated theoretical approach. Academy of Marketing Science Review, 2004(1), 1-32.

30. Suranovic, S. (2004). The Theory of Comparative Advantage: An Overview. C1997-2003. Retrieved on 2/17/04 from: http://internationalecon.com/v1.0/ch40/40c000.html.

31. Wren, D. A., (1994). The evolution of management thought. John Wiley \& Sons, Inc., New York.

32. Wren, D.A. and Greenwood, R. G., (1998). Management innovators. Oxford University Press, New York. 


\section{NOTES}

